\title{
The Determinants of Export Performance in a Small Open Economy: The Case of Sierra Leone
}

\author{
Abu Bakarr Tarawalie*, Morris Conteh \\ Department of Economics and Commerce, Fourah Bay College, University of Sierra Leone, Freetown, Sierra Leone \\ Email address: \\ tarawalieabu@yahoo.com (A. B. Tarawalie), morrismconteh123@gmail.com (M. Conteh) \\ ${ }^{*}$ Corresponding author
}

\section{To cite this article:}

Abu Bakarr Tarawalie, Morris Conteh. The Determinants of Export Performance in a Small Open Economy: The Case of Sierra Leone. International Journal of Economics, Finance and Management Sciences. Vol. 9, No. 1, 2021, pp. 1-6. doi: 10.11648/j.ijefm.20210901.11

Received: January 19, 2021; Accepted: January 28, 2021; Published: February 2, 2021

\begin{abstract}
The main objective of this paper is to investigate the determinants of export performance in Sierra Leone. The study uses annual time series data from 1980 to 2018 within the ARDL bound testing framework. The stationarity test indicates that all the variables are I(1) series, whilst the bound test result shows there is cointegration. The result reveals that FDI, REER and dummy variable for war are the main determinants of export performance in the long run. Also, the result confirms that FDI and inflation are the significant variables influencing export performance in the short run. Furthermore, with a coefficient of 0.51 , the result indicates that 51 percent of any disturbance emanating from previous year's shocks will be corrected in the current year. The diagnostic test reveals that, approximately 69 percent of the variation in export performance is determined by the exogenous variables as evident by the R-square value. Overall, the probability value of the F-statistic $(0.000000)$, shows that model is significant. The results of CUSUM and CUSUMSQ statistics indicate parameter stability. In order to improve the country's export performance, the paper recommends that government should ensure macroeconomic stability, design incentive mechanisms to encourage foreign direct investment and also maintain a politically stable economy.
\end{abstract}

Keywords: Export Determinants, Sierra Leone, ARDL, Annual Series

\section{Introduction}

The importance of export as a driver of economic growth has been acknowledged in the literature. International competitiveness remains a complex and multifaceted phenomenon, albeit an important feature of the economic performance of a country. Export performance is an integral component of international competitiveness as exports signal a country's success in international trade. Thus, an understanding of the dynamics of a country's export performance will help design better policies. It is widely acknowledged that, export plays a significant part in an economy, which serves as an engine for economic growth. Rising exports has the tendency to boost aggregate demand and promote growth. High Export performance may improve a country's balance of payments, increase the level of employment and boost economic growth.

The literature has put forward two schools of thought in explaining the drivers of export performance. The first school emphasizes that export is largely driven by external factors (i.e., export demand), Whilst the other school stresses factors that are internal to a particular country (export supply). However, the export performances of a given economy are largely influenced by both internal and external factors with different level of magnitude. The empirical literature is inconclusive in explaining the key drivers of export performance.

Despite the global decline in trade barriers over the last two decades, export performance produced mixed results across countries, as world exports increased by almost 220 per cent in the past twenty years. Export performance however leapfrogged to 720 per cent for East Asian and Pacific countries and falls to 80 per cent for Sub-Saharan countries. The export performance of Sub-Saharan Africa (SSA) declined over the last three decades, losing its share of world exports by over $250 \%$ over the last 30 years Lyakurwa [1]. Most of the countries in SSA experienced poor export performance over the years, largely due to over dependence on primary commodities, with little value addition and high risk of international price volatility. 
The Sierra Leone economy is fragile, typified by low export earnings, large and persistent trade deficit, rising inflationary pressure, lingering exchange rate depreciation, large fiscal deficits, chronic BOP deficit, and high public debt, among others (see Table 1). The Sierra Leone economy is further classified into a large traditional rural sector and a small modern urban sector. The Agricultural sector represent a-third of the country's export. Exports from the traditional sector includes cash crops such as cocoa, tobacco, ginger and palm oil. However, since 2012, mining has become the largest foreign exchange earners, whilst manufacturing sector remains small, contributing only $2 \%$ of GDP. The country's total exports are however growing albeit at a slow pace, at an averaging 21.2 percent between 1991-2015. The surge in export between 2011-2015, was largely on account of iron ore export. However, the country's export sector, which constitute both traditional and non-traditional exports remain low; demonstrated by smaller value of export to GDP ratio and declining share of export in total trade. The country has implemented various trade policy reforms to boost domestic export and improve the trade deficit, including the five-year (2010-2015) trade and fiscal policy reforms aimed to promote export by providing series of incentive measures. Despite much needed effort devoted to improve the export performance, the country continues to suffer from the problem of trade deficit owing to the decline in export performance amidst growing import.

Table 1. Selected Macroeconomic Indicators.

\begin{tabular}{llllll}
\hline Indicators & $\mathbf{1 9 9 1 - 9 5}$ & $\mathbf{1 9 9 6 - 2 0 0 0}$ & $\mathbf{2 0 0 1 - 2 0 0 5}$ & $\mathbf{2 0 0 6 - 2 0 1 0}$ & $\mathbf{2 0 1 1 - 2 0 1 5}$ \\
\hline Export (\% of GDP) & 24.6 & 15.7 & 20.8 & 18.1 & 27.0 \\
Trade Balance (\% of GDP) & -13.7 & -29.3 & -18.6 & -10.3 & -18.3 \\
Inflation (period average) & 59.2 & 20.1 & 7.8 & 12.7 & 11.5 \\
Real GDP growth (\%) & -2.9 & 2.9 & 16.8 & 5.2 & 4.2 \\
\hline
\end{tabular}

Sources: IFS and WDI, Various issues

The paradigm shifts of Sierra Leone's exports from traditional commodities such as coffee, cocoa, piassava, towards non-traditional products including minerals, such as diamond, iron ore, bauxite and gold, coupled with the persistent balance of payment deficit, is an indication that, the attainment of robust economic growth and high employment would have substantial effect on the performance of the economy. Since 2012, the mining sectorparticularly iron ore, has been the main driver of the country's economic growth. It is worthy to note that, government's reliance on external assistance for budgetary support is gradually declining. The Ebola outbreak in 2014, coupled with drop in global commodities prices, caused a significant contraction of economic activity in all areas. However, economic activities rebounded in 2017, following the end of the Ebola epidemic and surge in iron ore exports.

Thus, the important question that this paper seeks to address is: What are the fundamental determinants of export in Sierra Leone? Answer to this question has significant policy implications. Against this background, this paper empirically investigates the main determinants of export performance in Sierra Leone using the ARDL bound testing approach, with annual time series data from 1980 to 2018. This paper contributes to the debate on the drivers of export performance, given that despite the abundant empirical discussions on the determinants of export, there is no country specific study on Sierra Leone, a small open economy. Furthermore, notwithstanding the implementation of prudent export promotion policies and reforms, the country's export performance remains low. Thus, a study of this nature will provide an idea on the drivers of export performance in Sierra Leone context. The rest of the paper is structured as follows: Section 2 discusses the empirical findings of previous researches, while Section 3 focuses on the methodology including the model specification and estimation techniques. Section 4 presents the empirical analysis, and section 5 provides the conclusion and suggests policy recommendation to enhance export performance in Sierra Leone.

\section{Literature Review}

Empirical research studies on the determinants of export performance is abounding. Many researchers across the global have carried out empirical works with conflicting outcomes. Considering country specific studies, Epaphra [2] conducted a study to examine the factors influencing export performance in Tanzania from 1966 to 2015. The study employs the Johansen cointegration and Granger causality approach. The findings show that real per capita GDP, trade liberalization, and exchange rate have positive impact on export performance, and a negative relationship found between exports and official development assistance. Muhammad [3] examines the relationship between trade openness and inflation in Pakistan from 1947 to 2007. The result reveals a positive relationship between inflation and trade. Hervé, et al [4] carried out a study to examine the determinants of export performance in Zanzibar, using OLS for the period 1980-2005. The result shows that the price of exported products, has a positive impact on export performance. In a more recent study, Sayed et al [5] conducted a study that investigates the impact of supply-side factors on the export performance of Pakistan from 1971 to 2014. Based on ARDL model, the long run result suggests that the relative prices have a larger impact on the export performance of raw materials and value-added manufactured product. Also, the relative price, cost of production, and production capacity showed mixed effects for the export supply in the short run.

Using panel data, Uysal, and Mohamoud [6] carries out a 
study to identify the determinants of export performances of seven East Africa countries. Using panel data from 1990-2014, the results show that labor force, industrialization, foreign direct investment, and exchange rate have positive impact on export value, whilst inflation has a negative impact. Furthermore, Hsiao and Hsiao [7] investigates the relationship between foreign direct investment, export, and gross domestic product for eight East and Southeast Asian economies. The study employs the Granger causality test with data for the period 1986 and 2004. The result confirms a bidirectional causality between exports and GDP. Balogun [8] uses data from 1990:1 to 2004:4 for 5 West African countries (Sierra Leone, Ghana, Nigeria, Guinea and The Gambia) to analyze the impact of exchange rate policies on export supply. The results shows that domestic output, export prices and exchange rates have positive impact on export, while foreign income has a negative impact on export performance. Mohamad et al [9] examine the role of the real exchange rate and other macroeconomic variables on the export performance of Indonesia, Singapore, Malaysia and Thailand. The finding shows that appreciation of real exchange rate has a negative impact on export performance in these countries. Rodrick [10] investigates the determinants of export using 37 sub-Saharan Africa countries, using a panel data from 1964 to 1994 . The regression result establishes that GDP has a significant effect on export. Tyler [11] investigates the determinants of export growth for 55 countries from 1960 to 1977. The result confirms a positive relationship between export growth and economic growth. Also, Kumar [12] investigates the determinants of export performance in the developing countries. The result confirms that GDP has a positive effect on exports. Furthermore, Fugazza [13] examine the determinants of export performance for 84 countries from 1980 to 1999 . The finding shows that GDP has a positive impact on export performance. The empirical literature has produced conflicting result, hence a study on Sierra Leone will help policy makers to implement prudent policies to boost export performance.

\section{Methodology}

The empirical literature suggests that export performance is determined by both domestic and external factors. Given that Sierra Leone is a small open economy, exporters are therefore considered as price taker in the export market. It follows that, we can specify a single export model as a function of several indicators. The theoretical foundation for the model specification is premised on the neoclassical and Keynesian paradigms. The neoclassical school hypothesizes that export supply is largely influenced by the relative prices and productivity capacity, whilst Keynesian doctrine suggests that, export supply is determined by domestic demand pressure. Thus, the export model specified in this paper draws largely from theoretical foundation and empirical literature. The model also draws largely from the structural dynamics of the Sierra leone economy.

The functional specification of the export model is given as follows:

$$
\mathrm{EXP}=\mathrm{f}(\mathrm{RGDP}, \mathrm{CPI}, \mathrm{REER}, \mathrm{TOT}, \mathrm{FDI}, \mathrm{DW})
$$

Where; EXP represent total export as a percent of GDP, RGDP represent Real GDP growth, CPI is Consumer Price Index, REER represent Real effective Exchange Rate, TOT represent Terms of Trade measured as the ratio between the country's export price and import price, FDI is Foreign Direct Investment expressed as a percent of GDP, and DW is dummy variable, representing political stability, and takes a value 1 for war period (1991-2000) and zero elsewhere. Thus, for estimation purposes, the functional export model specified in equation (1) can be specified in a log-linear relationship as follow:

$$
\log E X P_{t}=\alpha_{0}+\beta_{1} \log R G D P_{t}+\beta_{2} \log C P I_{t}+\beta_{3} \log R E E R_{t}+\beta_{4} \log T O T_{t}+\beta_{5} \log F D I_{t}+\lambda D W+\varepsilon_{t}
$$

Where $\alpha$ and $\beta_{\mathrm{i} \text { 's }}(\mathrm{i}=1, \ldots \ldots, 5)$ are unknown parameter to be estimated; $\lambda$ is the coefficient representing dummy variable; $\varepsilon$ is disturbance term and $t$ is the time frame. The variables in Equation (2) are expressed in natural logarithm, hence the estimated coefficients are interpreted as elasticities.

To estimate the export function for Sierra Leone as specified in equation (2), the we employ the autoregressive distributed lag (ARDL) model popularized by Pesaran et al [14]. The justification for the use of the ARDL model is premised on the fact that it is applicable for small sample size; also, it is applicable to a model that includes both $\mathrm{I}(0)$ and $\mathrm{I}(1)$ variables. To conduct cointegration test using the ARDL model, we proceed by specifying an unrestricted ARDL export model and its determinants. This is done by transforming the export model specified in equation (2) as follows:

$$
\begin{aligned}
& \triangle \log E X P_{t}=\beta_{0}+\sum_{i=1}^{p} \beta_{1} \Delta \log R G D P_{t-i}+\sum_{i=1}^{q} \beta_{2} \Delta \log C P I_{t-i}+\sum_{i=1}^{r} \beta_{3} \Delta \log R E E R_{t-i}+\sum_{i=1}^{s} \beta_{4} \Delta \log \operatorname{lOT}_{t-i}+\sum_{i=1}^{v} \beta_{5} \Delta \log F D I_{t-i}+ \\
& \alpha_{1} \log R G D P_{t-1}+\alpha_{2} \log C P I_{t-1}+\alpha_{3} \log R E E R_{t-1}+\alpha_{4} \log T O T_{t-1}+\alpha_{5} \log F D I_{t-1}+\lambda D W+\varepsilon_{t}
\end{aligned}
$$

Where $\Delta$ is the difference operator, $\beta_{0}$ is the constant term $\beta_{\mathrm{i}}(\mathrm{i}=1, \ldots ., 5)$ are coefficients of the short run. i.e., they are the short run elasticities. Also, $\alpha_{i}(i=1, \ldots \ldots, 5)$ are the long run elasticities.

Based on the unrestricted ARDL export model specified in equation (3), we proceed to conduct the cointegration using the ARDL bound testing. In the first instance, we identify the optimal lag length for each variable. The study utilizes the AIC, SBC, H-Q and the LR statistics to determine the optimal lag length for the variables in the model. Once we obtain the ideal lag length, we determine the existence of cointegration from the F-statistics in equation (3). To test for cointegration, we set the null hypothesis of no cointegration by subjecting the coefficients of the long-run estimation 
equal to zero. We also set the alternative hypothesis that the long run coefficients are not equal to zero. Using the Wald test, we present the null and alternative hypotheses as:

$$
\begin{gathered}
H_{0}=\alpha_{1}=\alpha_{2}=\alpha_{3}=\alpha_{4}=\alpha_{5}=0 \text { (No cointegration) } \\
H_{0} \neq \alpha_{1} \neq \alpha_{2} \neq \alpha_{3} \neq \alpha_{4} \neq \alpha_{5} \neq 0 \text { (Cointegration) }
\end{gathered}
$$

The ARDL bound test to cointegration provides two asymptotic critical values; the lower critical bound valueswhich assumes that the variables. I (0); and the upper critical bound values- which also assumes that the variables are I (1). If the F-statistic is greater than the upper critical value, we reject the null hypothesis, and therefore concludes the existence of cointegration. On the other hand, if the Fstatistic is less than the lower critical value, then we conclude there is no cointegration.

Once we confirm there is cointegration, we then estimate a restricted ARDL error correction model.

$$
\triangle \log E X P_{t}=\beta_{0}+\sum_{i=1}^{p} \beta_{1} \Delta \log R G D P_{t-i}+\sum_{i=1}^{q} \beta_{2} \Delta \log C P I_{t-i}+\sum_{i=1}^{r} \beta_{3} \Delta \log R E E R_{t-i}+\sum_{i=1}^{s} \beta_{4} \Delta \log \operatorname{loT}_{t-i}+\delta E C T_{t-1}+\varepsilon_{t}
$$

Equation 4 is the short run restricted ARDL-ECM model, which consists of error correction term (ECT) and variables in first difference. The coefficient of ECT term $(\delta)$ shows the direction of change (speedy of adjustment) towards long run equilibrium.

Annual time series data from 1980 to 2018 were obtain for the variables in the model. Data was obtained from the International Financial Statistics year book and the Bank of Sierra Leone data base. The study conducted several diagnostic tests to validate the robustness of the regression results and the stability of the model. The study further presents the results of the R-square and adjusted R-square statistics.

\section{Empirical Results and Discussions}

\subsection{Unit Root Test Results}

The study conducted stationarity tests in order to confirm the order of integration. Both the ADF and PP tests were applied to determine the stationarity of the variables in the model. The result of the unit root tests as presented in Table 2 . indicates that all the variables are non-stationary in levels,

\begin{tabular}{|c|c|c|c|c|c|}
\hline \multirow{2}{*}{ Variables } & \multicolumn{2}{|c|}{ Augmented Dickey-Fuller } & \multicolumn{2}{|c|}{ Phillips Perron } & \multirow{2}{*}{ Order of integration } \\
\hline & Level & $1^{\text {st }}$ difference & Level & $1^{\text {st }}$ difference & \\
\hline EXP & -2.8832 & -5.3456 & -2.6908 & -7.9395 & I (1) \\
\hline GDP & 0.2309 & -7.9395 & 0.3252 & -5.3047 & $\mathrm{I}(1)$ \\
\hline FDI & -1.5401 & -6.7494 & -1.4606 & -7.9827 & $\mathrm{I}(1)$ \\
\hline REER & -2.0485 & -3.6210 & -1.7158 & -3.4815 & I (1) \\
\hline CPI & -1.1941 & -3.4668 & -2.1739 & -4.8044 & I (1) \\
\hline TOT & -2.1437 & -4.8278 & -2.3149 & -10.4384 & $\mathrm{I}(1)$ \\
\hline
\end{tabular}
but became stationary in their first difference.

Table 2. Results of Unit Root Test.

Source: Eviews 11 output; 5 percent critical value $=-2.9411$

\subsection{Cointegration Test Results}

Table 3. Bound test cointegration result.

\begin{tabular}{lllll}
\hline Test statistic & value & Significance & I (0) & I (1) \\
\hline $\mathrm{n}=1000$ & & & & \\
F-statistic & 5.927 & $10 \%$ & 2.12 & 3.23 \\
$\mathrm{k}$ & 6 & $5 \%$ & 2.45 & 3.65 \\
& & $2.5 \%$ & 2.75 & 3.99 \\
& & $1 \%$ & 3.15 & 4.43 \\
\hline
\end{tabular}

The study utilizes the ARDL bound test to determine the existence of cointegration. The philosophy behind the bound test to cointegration is to ascertain the existence of a long run relationship. To perform the bound test, we specify the null hypothesis $\left(\mathrm{H}_{0}\right)$ with the assumption of no cointegration, against the alternative hypothesis $\left(\mathrm{H}_{1}\right)$ of cointegration. The bound test generates the F-statistics, and the guiding principle is that, when F-statistic is greater than $1 \%$ and $5 \%$ upper bounds, we conclude that there is cointegration. The cointegration result presented in Table 3, reveals the calculated F-statistics (5.93) is higher than the 5\% (3.65) and $1 \%$ (4.43), upper values. The result therefore confirms the existence of cointegration among the export function and its key determinants. We therefore proceed with the estimation of both long-run and short-run models within the ARDL framework.

\subsection{Long Run Analysis}

The long run model was estimated with variables in level. The long run regression results as presented in Table 4, indicates that FDI, REER and dummy variable for war are the main long-run determinants of export performance in Sierra Leone. Specifically, the result reveals an inverse relationship between REER and export performance with a significant coefficient. Intuitively, an appreciation of the exchange rate by 1 percent will cause export performance to decline by approximately 0.2 percent during the study period. The intuition is that, despite the persistent nominal depreciation, the surge in domestic prices in relation to foreign prices will cause an appreciation of the real effective exchange rate, and makes export less competitive, leading to a fall in export performance. This result is not at variant with findings by Edwards and Alves [15]; Morrissey and Mold [16]. 
Similarly, the dummy variable for war is significant and has a negative effect on export performance during the study period. Intuitively, the civil war disrupted economic activities in the export sector, including agriculture, mining, and manufacturing, with the resultant consequences of reduced export performance. The result further shows that a 1 percent increase in FDI will boost export by 0.4 percent. FDI inflows that boost infrastructure development and increased technological innovation in the export sector, especially the mining sector will result to increase export performance. Similar result was obtained by Sharma [17] for India.

Table 4. Long run results.

\begin{tabular}{lllll}
\hline Variables & Coefficient & Std. Error & t-Stat & Prob. \\
\hline LNGDP & 0.18538 & 0.09487 & 1.95404 & 0.1224 \\
LNFDI & 0.40133 & 0.11255 & 3.56579 & 0.0018 \\
LNREER & -0.22598 & 0.07515 & -3.00705 & 0.0030 \\
LNCPI & -2.84688 & 1.450763 & -1.962323 & 0.1609 \\
LNTOT & -2.750012 & 2.890012 & -0.949695. & 0.3514 \\
DUM & -0.18451 & 0.06745 & 2.735169 & 0.0313 \\
\hline
\end{tabular}

Source: Authors' compilation from Eviews 11 output

\subsection{Short Run Analysis}

The result of the short run result as given in Table 5 confirms that foreign direct investment and inflation are the significant variables influencing export performance in Sierra Leone, a result similar to the long run dynamics. The result reveals that, the coefficient of the ECT $(-1)$ is negative and significant. With a coefficient of 0.51 , the result indicates that 51 percent of any disturbance emanating from previous year's shocks will be corrected in the current year. Also, inflation has a negative impact on export. A 1 percent surge in inflation will reduce export by 0.2 percent. The literature suggests that inflationary pressure will impact export via its direct impact on inputs cost, as well as on interest rate. As a result, the cost of production will increase and return on investment decrease, with severe impact on the country's export competitiveness.

The diagnostic test results reveal that, approximately 69 percent of the variation in export performance is determined by the exogenous variables as evident by the R-square value. Overall, the probability value of the F-statistic (0.000000), shows that model is significant whilst the Durbin-Watson statistic of 2.300080 confirms the existence of no autocorrelation in the residuals.

Table 5. Short run results (1, 2, 2).

\begin{tabular}{lllll}
\hline Variable & Coefficient & Std. Error & t-Stat. & Prob. \\
\hline C & -5.0420 & 0.70003 & -7.202512 & 0.0000 \\
D(LNFDI) & 0.276786 & 0.078464 & 3.527547 & 0.0024 \\
D(LNCPI(-1)) & -0.22188483 & 0.04767 & -4.654868 & 0.0002 \\
D(LNGDP) & -0.037230 & 0.01490 & -2.497955 & 0.1673 \\
ECT(-1) & -0.51447 & 0.114687 & -4.4857 & 0.0003 \\
R-squared & 0.692603 & Adjusted R-squared & 0.647007 \\
Durbin-Watson stat & 2.105 & Prob (F-Statistics) & 0.000000 \\
\hline
\end{tabular}

Source: Authors' compilation from Eviews 11 output

\subsection{Stability Test}

To test for the stability of the parameter, we conducted a stability test which involves the cumulative sum (CUSUM) of recursive residuals and the CUSUM of square (CUSUMSQ) tests as popularized by Pesaran and Pesaran [18]. The literature suggests that, the CUSUM test determine systematic changes in the regression coefficients, and CUSUMSQ identify sudden changes from the constancy of the regression coefficients. The results as presented in Figures 1 and 2, respectively, shows that, CUSUM and CUSUMSQ statistics fall inside the critical bands indicating that, there exists stability in the coefficients.

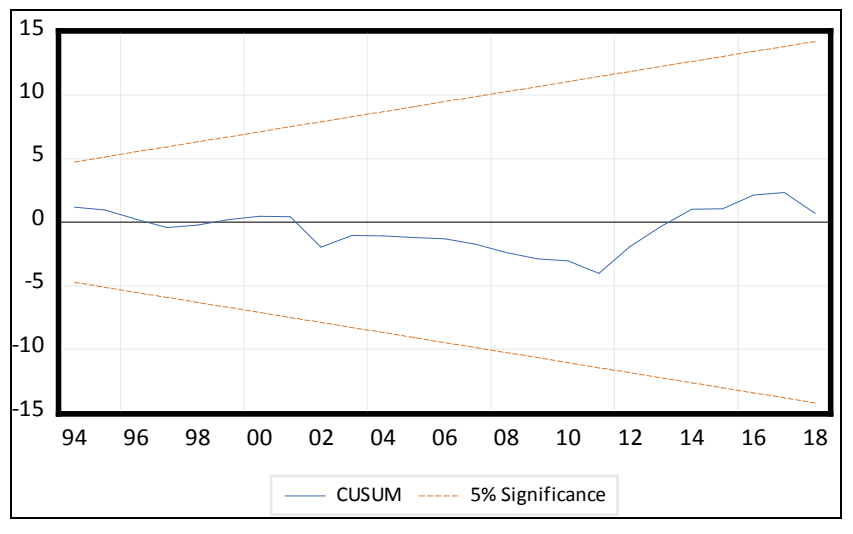

Source: EViews 11 output

Figure 1. Result of CUSUM Test.

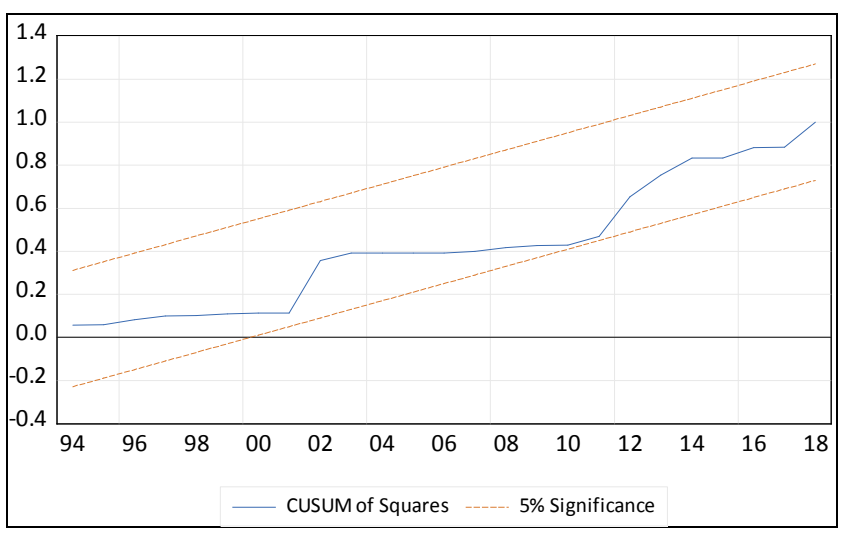

Source: EViews 11 output

Figure 2. Result of CUSUMSQ Test.

\section{Conclusion and Recommendations}

This paper investigated the determinants of export performance in Sierra Leone from 1980 to 2018. The study employed the ARDL framework approach to examine the long-run and short-run dynamics.

The stationarity test result established that all the variables are I(1) series, whilst the bound test result confirmed there was cointegration. The result revealed that FDI, REER and dummy variable for war are the main determinants of export performance in the long run. Furthermore, the short run result confirmed that FDI and inflation are the significant variables 
influencing export performance in the short run. The findings also showed that, the error correction term ECT (-1) has a coefficient of -0.51 , which intuitively imply that 51 percent of any disturbance emanating from previous year's shocks will be corrected in the current year. The diagnostic test revealed that, approximately 69 percent of the variation in export performance is determined by the exogenous variables as evident by the R-square value. Overall, the probability value of the F-statistic (0.000000), shows that model is significant. The results of CUSUM and CUSUMSQ statistics indicate parameter stability.

The study suggested some policy recommendations to boost the country's export potential. The government is encouraged to design incentive mechanisms to encourage foreign direct investment. This has the potential to improve the country's export base, and also attracts foreign exchange and capital technology. Also, policies aimed at maintaining economic stability, including price and exchange rate stability, would improve the country's export performance. Ensuring stability in domestic prices and avoiding exchange rate volatility and fluctuations, will not only reduce the cost of doing business, but will also encourage investment in productive sectors especially export sector. Also, there is a need to maintain a politically stable economy that provides a conducive atmosphere for investment in the export sector and for business to thrive. A stable environment devoid of political instability has the potential to promote economic activity and boost real GDP growth, with positive spill-over towards enhancing the country's export performance.

\section{References}

[1] Lyakurwa, W. M. (1998). Primary exports and primary processing for export in sub-saharan Africa. A Paper presented at the AERC/UNU Conference on Asia Global and Africa on Economy, Tokyo, August 3-4.

[2] Epaphra, M (2016). Determinants of Export Performance in Tanzania. Journal of Economics Library, Vol 3 (3).

[3] Muhammad, Z. (2010). Openness and inflation: Evidence from time series data. Doğuş Üniversitesi Dergisi, 11 (2).

[4] Hervé, D. B. G., Amoro G., Mahfoudh R. S. and Constant N. Z. S. (2014). The Determinants of Export Performance: The Case Study of Zanzibar Export. International Journal of Economics and Finance, 6 (6), 95-102.
[5] Sayed, I. H, Akhtar, H and Muhammad, M. A (2020). Determinants of export supply in Pakistan: A sector wise disaggregated analysis, Cogent Economics \& Finance, 8: 1, 1732072 .

[6] Uysal, Ö and Mohamoud, A. S (2018). Determinants of Export Performance in East Africa Countries. Chinese Business Review, Apr. Vol. 17, No. 4, 168-178.

[7] Hsiao, F. S. T., \& Hsiao, M. W. (2006). FDI, exports, and growth in East and Southeast Asia: Evidence from time-series and panel data causality analyses. Paper presented at 2006 International Conference on Korea and the World Economy V, Seoul, Korea.

[8] Balogun, E. D. (2007). Effects of exchange rate policy on bilateral exports trade of WAMZ countries, MPRA Working Paper, No. 6234.

[9] Mohamad, S., Nair, M., \& Jusoff, K. (2009). Exchange rates and export competitiveness in selected ASEAN economies. International Business Research, 2 (2), 156-166.

[10] Rodrick. D. (1999). The new global economy and developing countries making openness work. Washington: Overseas Development Council.

[11] Tyler, W. G. (1981). Growth and export expansion in developing countries: Some empirical evidence. Journal of Development Economics, 9 (1), 121-130.

[12] Kumar, N. (1998). Multinational enterprises, regional economic integration, and export platform production in the host countries: An empirical analysis for the US and Japanese corporations. eltwirtschaftliches Archiv, 134, 450-483.

[13] Fugazza, M (2004), Export Performance and Its Determinants: Supply and Demand Constraints, Policy Issues in International Trade \& Commodities Study Series No. 26, UNCTAD.

[14] Pesaran, M. H., Shin, Y., \& Smith, R. J. (2001). Bounds testing approaches to the analysis of level relationships. Journal of Applied Econometrics, 16 (3), 289-326.

[15] Edwards, L and Alves, P (2006). South Africa's export performance: determinants of export supply. South African Journal of Economics Vol. 74: 3 September.

[16] Morrissey, O., \& Mold, A. (2006). Explaining Africa's Export Performance-Taking a New Look. Discussion paper.

[17] Sharma, K. (2000). Export growth in India: Has FDI played a role? Charles Sturt University, Discussion paper, No 816.

[18] Pesaran, M. H., Pesaran, B. (1997), Working with Microfit 4.0: Interactive Econometric Analysis. Oxford: Oxford University. 